\title{
MOLECULAR CHARACTERIZATION AND COMPARISON OF MULTI DRUG RESISTANT STRAINS OF MYCOBACTERIUM TUBERCULOSIS BY PHENOTYPIC AND GENOTYPIC METHOD
}

\author{
Bhatt $C P^{1,2}$, Bhatt $A B^{2}$, Shrestha $B^{3}$ \\ ${ }^{1}$ Kathmandu Medical College, Kathmandu, Nepal \\ 2 Hemwati Nandan Bahuguna Garhwal University, Srinagar, Garhwal India \\ ${ }^{3}$ German- Nepal Tuberculosis Project, Kathmandu, Nepal
}

\begin{abstract}
Introduction: Drug resistant tuberculosis is a significant threat to tuberculosis control because only a few effective drugs are available against M. tuberculosis. The aims of this study were to compare multi drug resistant (MDR) strains of tuberculosis by phenotypic and genotypic method and determine type, location and frequency of $r p o B$ and $K a t G$ gene mutations.
\end{abstract}

Methodology: Anti-tuberculosis drugs susceptibility test of M. tuberculosis grown on Lowenstein Jensen medium was performed by proportion method. MDR cases were analyzed for mutation of rpoB and KatG genes. The regions of these genes were amplified by polymerase chain reaction (PCR) and sequenced.

Results: Two different mutations were identified in rifampicin resistant strains. The most common point mutations were in codons TCG $531 \rightarrow$ TTG $(85 \%)$ and GAC $516 \rightarrow$ TTC $(15 \%)$ of the rpoB gene. Two different mutations in KatG gene were detected. The most common KatG point mutations were AGC 315 ACC (Ser $\rightarrow$ Thr) (85\%) and CGG 463 CTG (Arg $\rightarrow$ Leu) (10\%). In this study DNA sequencing analysis did not find mutation on KatG gene of one of the strain tested. Male and female were equally affected by MDR tuberculosis and majorities (35\%) of them were found in 21-30 years age group.

Conclusion: The present investigation agrees that genetic mutation is responsible for change in phenotypic characteristics of M. tuberculosis.

Key words: Mycobacterium tuberculosis, Multi drug resistant, KatG, rpoB

\section{INTRODUCTION}

The complete genome of $M$. tuberculosis strain has been mapped as a length of about 4. 4Mb, However, each gene of $M$. tuberculosis may have separate function including the specific complex formation with important drugs being used as tuberculosis treatment regime. Unusual genetic alteration of

\begin{tabular}{l}
\hline Correspondence: \\
Dr. Chandra Prakash Bhatt, Ph D \\
Associate Professor \\
Department of Microbiology, Kathmandu Medical College \\
Kathmandu, Nepal. \\
E-mail: drcpbhatt@yahoo.com, \\
drcpbhatt@gmail.com
\end{tabular}

bacterial genes leads to the development of drug resistance.

The KatG encodes catalase-peroxidase which is necessary to activate INH to a toxic substance in the bacterial cell. ${ }^{1}$ This toxic substance subsequently affects intracellular targets such as mycolic acid biosynthesis which eventually results in loss of cellular integrity and the bacteria die. ${ }^{2}$ Middlebrook et al. initially demonstrated that a loss of catalase activity can result in $\mathrm{INH}$ resistance. ${ }^{3}$ The majority of INH-resistant clinical isolates become resistant by losing or altering KatG activity, nevertheless, only KatG mutations do not account for all observed INH resistance, but mutations in another putative INH 
target called inhA also. The Ser315Thr substitution is estimated to occur in $30-60 \%$ of INH resistant isolates. ${ }^{4,5,6}$ The KatG (CGG463CTG) (Arg-Leu) amino acid substitutions is the most common polymorphism found in the KatG gene and is not associated with $\mathrm{INH}$ resistance.

Rifampicin (RIF) binds to the $\beta$-subunit of DNAdependent RNA polymerase hindering transcription and thereby killing the organism. Extensive studies on the rpoB gene in RIF resistant isolates of $M$. tuberculosis identified a variety of mutations and short deletions in the gene. A total of 69 single nucleotide changes; 3 insertions, 16 deletions and 38 multiple nucleotide changes have been reported. ${ }^{7}$ More than $95 \%$ of all missense mutations are located in a $81 \mathrm{bp}$ core region (Rifampicin resistance determining region) of the $r p o B$ gene between codons 507-533 with the most common changes in codons Ser531Leu, His526Tyr and Asp516Val. These changes occur in more than $70 \%$ of RIF resistant isolates. ${ }^{4,8,7}$

Drug susceptibility testing (DST) of $M$. tuberculosis in clinical specimens is time-consuming. INH and RIF are crucial elements of the standard treatment regimen of tuberculosis, and resistance to these drugs requires extension of therapy. ${ }^{9}$ Proportion method is a widely used method, especially in resource-limited settings (RLS). It uses solid media, Lowenstein-Jensen to determine the proportion of resistant mutants to a given drug. Its turnaround time (TAT) is between 4-6 weeks. ${ }^{10,11}$ The vast majority of RIF resistance is caused by mutations located in the 81-bp region of the $r p o B$ gene. $^{12} \mathrm{INH}$ resistances are more complex, as the mutations conferring resistance are located in several genes and loci. INH resistance has been associated mainly with mutations in KatG, inhA, ahpC, and kas.A. ${ }^{13-16}$ Sequencing of PCR-amplified products of rpoB and KatG has become the most widely used genotypic method for detecting drug resistance in M. tuberculosis; it is accurate and reliable and it has become the reference standard for mutation detection. ${ }^{17}$ DNA sequencing has been widely used for characterizing mutations in the rpoB gene in RIF-resistant strains and to detect mutations responsible for resistance to other antituberculosis drugs. ${ }^{12,18,19}$

Aims of this study were to compare multi drug resistant cases of tuberculosis by phenotypic and genotypic method and determine types, location and frequency of mutation on rpoB and KatG.

\section{METHODOLOGY}

This study was carried out at the GENTUP Kathmandu and HNB Garhwal University during January 2008 to December 2008. Ethical approval was taken. Data on the MDR-TB patients were collected and recorded on a standardized form. The data were collected on age, gender and type of disease (new or old). This study included 9 primary and 11 acquired drug resistant cases. The research objectives and methods were explained to the patients and verbal consent obtained from them before the sputum samples were collected. The cases were selected using random sampling technique. Drug susceptibility test was performed on $M$. tuberculosis isolates by proportion method as standard protocol.20 M. tuberculosis strains were tested against four antibiotics used in DOTS program of Nepal such as isoniazid, rifampicin, ethambutol and streptomycin.

Twenty multi drug resistant strains of $M$. tuberculosis were screened for mutations of $r p o B$ and KatG gene associated with resistance to rifampicin and isoniazid respectively by PCR-DNA sequencing method. Spin column method was used for extracting Mycobacterium tuberculosis DNA following the manufacturer instructions. ${ }^{21}$ The estimation of the extracted DNA from the samples was carried out using spectrophotometry method.22 A 210-bp and 750-bp segment of the katG gene and 411-bp fragments of the rpoB gene, containing the sequence of the 157-bp fragment were amplified by standard polymerase chain reaction (PCR). ${ }^{23}$

PCR amplified products were sequenced directly on an Applied Bio-systems ABI Prism 3100-Avant automated DNA sequencer. Sequencing was done with big dye terminator cycle sequencing kit from $\mathrm{ABI}$, following the manufacturer's instruction. 


\section{RESULTS}

Age wise distribution of MDR cases is shown in figure 1. Majority, $7(35 \%)$ of the MDR cases of tuberculosis were found in 21-30 years age group. Similarly gender wise distribution of MDR cases of tuberculosis were found equal in both the gender. Among twenty strains of MDR M. tuberculosis $15 \%$ and $40 \%$ were sensitive to streptomycin and ethambutol respectively. PCR-DNA sequencing results of MDR strains found $100 \%$ and $95 \%$ mutation in rpoB and KatG respectively and they correlated well with the phenotypic method (Table 1).

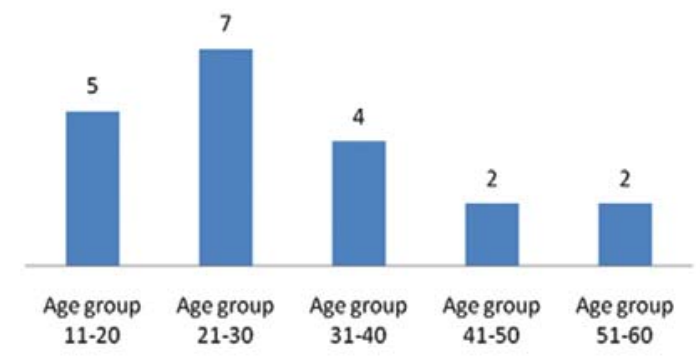

Figure 1. Age wise distribution of MDR strains

Table 1. DNA sequencing results of MDR strains of Mycobacterium tuberculosis

\begin{tabular}{|c|c|c|c|c|c|}
\hline $\begin{array}{l}\text { S. } \\
\text { No }\end{array}$ & Age & Sex & rpoB gene & $\begin{array}{l}\text { KatG } \\
\text { gene }\end{array}$ & Case \\
\hline 1 & 60 & M & TCG 531 TTG & S 315 T & New \\
\hline 2 & 42 & $\mathrm{~F}$ & TCG531 TTG & S 315 T & Old \\
\hline 3 & 25 & $\mathrm{~F}$ & TCG531 TTG & G 463 T & Old \\
\hline 4 & 24 & $\mathrm{~F}$ & TCG531 TTG & S 315T & New \\
\hline 5 & 15 & $\mathrm{~F}$ & GAC516 TTC & S 315T & Old \\
\hline 6 & 40 & $M$ & TCG531 TTG & S 315T & Old \\
\hline 7 & 16 & M & TCG531 TTG & S 315 T & New \\
\hline 8 & 35 & $M$ & TCG531 TTG & S 315 T & New \\
\hline 9 & 17 & $\mathrm{~F}$ & TCG531 TTG & S 315 T & New \\
\hline 10 & 38 & $M$ & TCG531 TTG & S 315 T & Old \\
\hline 11 & 23 & $F$ & TCG531 TTG & S 315 T & New \\
\hline 12 & 16 & $F$ & GAC516 TTC & S 315T & New \\
\hline 13 & 22 & $\mathrm{M}$ & TCG531 TTG & S 315 T & Old \\
\hline 14 & 30 & $M$ & TCG531 TTG & S 315 T & Old \\
\hline 15 & 56 & $M$ & TCG531 TTG & S 315 T & Old \\
\hline 16 & 25 & $M$ & GAC516-TTC & & Old \\
\hline 17 & 17 & $\mathrm{~F}$ & TCG531-TTG & S $315 \mathrm{~T}$ & New \\
\hline 18 & 36 & $\mathrm{~F}$ & TCG531-TTG & S 315 T & New \\
\hline 19 & 35 & $M$ & TCG531-TTG & G $463 \mathrm{~T}$ & Old \\
\hline 20 & 45 & $\mathrm{~F}$ & TCG531-TTG & S $315 \mathrm{~T}$ & Old \\
\hline
\end{tabular}

\section{DISCUSSION}

The mycobacterium uses various mechanisms to evade killing by drugs, including mutations in genes that code for drug target proteins, a complex cell wall which blocks drug entry, and membrane proteins that act as drug effux pumps. ${ }^{24,}{ }^{25}$ Along with HIVIAIDS, MDR-TB is the most important threat to TB control. Countries with a high MDRTB prevalence generally have a history of poor TB control. There are both preventive and restorative strategies to combat resistance-DOTS and DOTSPlus. The major barrier to MDR-TB treatment is the high cost of second line drugs which are at least 300 times more expensive than first line drugs based on Green Light Committee (GLC) prices and between 1000-3000 times more expensive when market prices are used. Additional barriers include extensive laboratory requirements to conduct culture and drug susceptibility testing (DST), severe adverse events associated with second-line drugs and fear of development of resistance to second line drugs. The misuse of second line drugs could lead to the creation of TB strains resistant to all known anti-TB drugs. ${ }^{26}$

Twenty MDR cases of $M$. tuberculosis were included in this study. Two loci associated with drug resistance were selected for characterization viz., rpoB (RIF) and KatG (INH). Two different mutations were identified in rifampicin resistant M. tuberculosis strains. The most common point mutations were in codons 531 (85\%) followed by $516(15 \%)$ of the ropB respectively. Similar study conducted by Sajduda et al. (2004)27 in Poland showed that nineteen different mutations were identified in 64 rifampicin resistant strains, and five new alleles were described. The most common point mutations were in codons $531(41 \%), 516(16 \%)$, and $526(9 \%)$ of the rpoB gene. These findings are in agreement with those reported by Spindola de Miranda et al. $(2001)^{28}$ the later showed that among rifampicin resistant strains a double point mutation which had not been reported before was detected in one strain from France. The mutations were found in codons 531 (31.2\%), 526, 513 and 533 (18.7\% each). In Brazilian strains the most common mutations were in codons $531(72.2 \%)$, $526(11.1 \%)$ and $513(5.5 \%)$. The heterogeneity 
found in French strains may be related to the fact that most of those strains were from African or Asian patients.

PCR-DNA sequencing of isoniazid resistant $M$. tuberculosis strains identified two different types of mutations in KatG. The most common point mutations were in codons $315(85 \%), A G C \rightarrow A C C$ (Ser $\rightarrow$ Thr) followed by $463(10 \%)$ CGG $\rightarrow$ CTG (Arg $\rightarrow$ Leu) of the KatG. Mutation were not found in $1(5 \%)$ in KatG of the isolate. Similar study conducted in Bostanabad et al. $(2008)^{29}$, showed that most mutations were in KatG gene codons 315,316 and 309. Four types of mutations were identified in codon 315: AGC $\rightarrow$ ACC $(85 \%)$, $A G C \rightarrow$ AGG $\quad(2.3 \%), \quad A G C \rightarrow$ AAC $\quad(4.7 \%)$, $A G C \rightarrow G G C(2.3 \%)$. The highest frequency of mutations sharing between primary and secondary infection was found in codon 315. Another similar study conducted by Sajduda et al. $(2004)^{27}$ in Poland showed that six different mutations in the KatG gene of 83 resistant strains were detected. Fifty-seven (69\%) isolates exhibited nucleotide substitutions at codon 315 . The majority of hot mutations in katG gene of $M$. tuberculosis have been reported in codon 315 (Ser $\rightarrow \mathrm{Thr}$ ) and less in other codons. ${ }^{30,31,32}$ Most reports suggest that resistance of $M$. tuberculosis to isoniazid mostly corresponds to changes in codon $315 .{ }^{31,33}$ Finding of this study were similar with $85 \%$ of all isolates showing mutation in codon 315 .

In this study sequencing analysis did not find mutation on KatG gene of one (5\%) of the strain tested, although that strain was resistant to isoniazid as determined by the proportion method. Other study revealed that a mutation associated with isoniazid resistance can also be located outside the KatG gene such as inhA gene, kasA gene, ndh gene and ahpC gene. ${ }^{27,34}$ Although this does not occur so frequently. In this case mutation may present to other genes. Other possibilities are that in this resistant strain other mechanism of resistance may be involved.

\section{CONCLUSION}

PCR-DNA sequencing shows MDR strains of $M$. tuberculosis isolates has mutation on $r p o B$ gene and $95 \%$ strains had mutation on KatG gene. The most common point mutations were found in codons 531 (85\%) of the ropB gene and codons $315(85 \%)$ of the KatG gene. This study showed that genetic changes in the $r p o B$ and $K a t G$ genes were more consistently associated with resistance phenotype.

\section{REFERENCES}

1. Zhang $Y$, Heym B, Allen B, Young D, Cole S. The catalase-peroxidase gene and isoniazid resistance of Mycobacterium tuberculosis. Nature 1992;358:591-93.

2. Barry CE III, Lee RE, Mdluli K, Sampson AE, Schroeder BG, Slayden RA, Yuan Y. Mycolic acids: structure, biosynthesis and physiological functions. Prog Lipid Res 1998;37:143-79.

3. Middlebrook G. Isoniazid-resistance and catalase activity of tubercle bacilli. Am Rev Tuberc 1954;69:471-72.

4. Ramaswamy S, Musser M. Molecular genetic bases of antimicrobial agent resistance in Mycobacterium tuberculosis: 1998 update. Tuber Lung Dis 79:329.

5. Musser JM, Kapur V, Williams DL, Kreiswirth BN, van Soolingen D, van Embden JD. Characterization of the catalase-peroxidase gene (katG) and inh A locus in isoniazid-resistant and susceptible strains of Mycobacterium tuberculosis by automated DNA sequencing: restricted array of mutations associated with drug resistance. J Infect Dis 1996;173:196-202.

6. Slayden RA, Barry CE. The genetics and biochemistry of isoniazid resistance in Mycobacterium tuberculosis. Microbes Infect 2000;2:659-69.

7. Herrera L, Jimenez S, Valverde A, Garciaranda MA, Saez-Nieto JA. Molecular analysis of rifampicinresistant Mycobacterium tuberculosis isolated in Spain (1996-2001). Description of new mutations in the rpoB gene and review of the literature. Int. J Antimicrob Agents 2003; 21: 403-8.

8. Rattan A, Kalia A, Ahmad N. Multi-drug resistant Mycobacterium tuberculosis: molecular perspectives. Emerg Infec Dis 1998;4:195-209. 
9. Blanc LP, Chaulet $M$, Espinal $S$, Graham $M$, Grzemska A, Harries $F$ et al. Treatment of tuberculosis, guidelines for national program, 3rd ed. World Health Organization, Geneva, Switzerland 2003.

10. Canetti G. Advances in techniques of testing mycobacterial drug sensitivity, and the use of sensitivity tests in tuberculosis control program. Bull Wld HIth Org, 1969;41:21-43.

11. Canetti G. Mycobacteria: Laboratory methods for testing drug sensitivity and resistance. Bull WId Hlth Org, 1963;29: 565-68

12. Telenti A, Imboden P, Marchesi F, Lowrie D, Cole S, Colston MJ, et al. Detection of rifampicin-resistance mutations in Mycobacterium tuberculosis. Lancet 1993;341:647-50.

13. Banerjee A, Dubnau $E$, Quemard $A$, Balasubramanian $\mathrm{V}$, Um KS, Wilson $\mathrm{T}$ et al. IntA, a gene encoding a target for isoniazid and ethionamide in Mycobacterium tuberculosis. Science 1994;263:227-30.

14. Kelley CL, Rouse DA, Morris SL. Analysis of ahpC gene mutations in isoniazid-resistant clinical isolates of Mycobacterium tuberculosis. Antimicrob Agents Chemother 1997;41:2057-58.

15. Mdluli K, Slayden RA, Zhu Y, Ramaswamy S, Pan $X$, Mead D et al. Inhibition of a Mycobacterium tuberculosis beta-ketoacyl ACP syntheses by isoniazid. Science 1998;280:1607-10.

16. Ramaswamy S, Musser JM. Molecular genetic basis of antimicrobial agent resistance in Mycobacterium tuberculosis: 1998 update. Tuber Lung Dis 1998;79:3-29.

17. Victor TC, Van Helden PD. Detection of mutations in Mycobacterium tuberculosis by a Dot Blot Hybridization Strategy. In: Mycobacterium tuberculosis Protocols. Methods in Molecular Medicine. Vol. 54. New Jersey: Humana Press 2001;155-64.

18. Garcia de Viedma D. Rapid detection of resistance in Mycobacterium tuberculosis: a review discussing molecular approaches. Clin Microbiol Infect 2003:9:349-59.

19. Jalava J, Marttila $H$. Application of molecular genetic methods in macrolide, lincosamide and streptomycin resistance diagnostics and in detection of drug-resistant Mycobacterium tuberculosis. APMIS 2004;112:838-55.

20. Fujiki A. TB Bacteriology Examination to Stop TB. The research institute of tuberculosis Japan (JATA). November 18, 2001.

21. Wade K, Aldous, June I Pounder, Joann L Cloud, Gail $L$ woods May. Comparison of six methods of extracting Mycobaterium tuberculosis DNA from processed sputum for testing by quantitative real time PCR. J Clin Microbiol Vol 2005;43:2471-73.

22. Sambrook J, Fritsch EF, Maniatis T. Molecular cloning: a laboratory manual. 2nd edn. Cold spring Harbor Laboratory Press, USA 1989.

23. Telenti A, Honore N, Bernasconi C, March J, Ortega A, Heym B et al. Genotypic assessment of isoniazid and rifampin resistance in Mycobacterium tuberculosis: A blind study at reference laboratory level. J Clin Microbiol 1997;23:719-23.

24. Cole ST, Brosch R, Parkhill J, Garnier T, Churcher C, Harris D. Deciphering the biology of Mycobacterium tuberculosis from the complete genome sequence. Nature 1998;393:537- 44.

25. Lweis K. Multidrug resistance pumps in bacteria: variations on a theme. Trends Biochem Sci 1994;19:119-23.

26. Stop TB working group on DOTS-Plus for MDR-TB strategic plan 2006-2015.

27. Sajduda A, Anna A, PopLawska M, Augustynowiez AK, Awolska Z, Niemann S. Molecular characterization of rifampicine-and isoniazidresistant Mycobacterium tuberculosis strains isolated in Poland. J Clin Microbiol 2004;42:242532.

28. Spindola de Miranda S, KritskiAL, Filliol I, C Mabilat C, Panteix G, Drouet E. Mutations in the rpoB gene of rifampicin-resistant Mycobacterium tuberculosis strains isolated in Brazil and France Mem Inst Oswaldo Cruz, Rio de Janeiro 2001;96:247-50.

29. Bostanabad SZ, Titov LP, Bahrmand A, Nojoumi SA. Detection of mutation in isoniazid resistant Mycobacterium tuberculosis isolates from tuberculosis patients in Belarus. Indian Journal of Medical Microbiology 2008;26:143-7.

30. Young DB. Ten years of research progress and what's to come. Tuberculosis 2003;83:77-81. 
31. Zheltokjva EA, Chernousova LN, Smirnova TJ, Andreevskaya SN, Yates M, Drobnievsky F. Molecular genetic typing Mycobacterium tuberculosis strains isolated from patents in the samapa region by the restriction DNA fragment length polymorphism ZH. Microbial (Moscow) 2004;5:39-43.

32. KentPT,KubicaGP.PublicHealthMycobacteriology: A Guide for the Level III Laboratory, US Department of Health and Human Services, Public Health Services, Centers for Disease Control. Atlanta 1985;1-207.
33. Herrera-Leon, Molina L, Saiz T, Saez-Nieto $P$, Jimenez JA. New multiplex PCR for rapid detection of isoniazid-resistant Mycobacterium tuberculosis clinical isolates. Antimicrob Agents Chemother 2005;49:144-7.

34. Igor M, Otten T, Filipenko M, Vyazovaya A, Chrapov $\mathrm{E}$, Limeschenko $\mathrm{E}$. Detection of isoniazid resistant Mycobacterium tuberculosis strains by a multiplex allele-specific PCR assay targeting KatG codon 315 variation. J Clin Microbiol 2002;5:2509-12. 